IZA DP No. 5712

Too Far to Go? Does Distance Determine Study Choices?

Stefan Denzler

Stefan C. Wolter

May 2011 


\title{
Too Far to Go? \\ Does Distance Determine Study Choices?
}

\author{
Stefan Denzler \\ Swiss Coordination Centre for Research in Education (SKBF) \\ and University of Lausanne \\ Stefan C. Wolter \\ Swiss Coordination Centre for Research in Education (SKBF), \\ University of Bern, CESifo and IZA
}

Discussion Paper No. 5712

May 2011

IZA

P.O. Box 7240

53072 Bonn

Germany

Phone: +49-228-3894-0

Fax: +49-228-3894-180

E-mail: iza@iza.org

\begin{abstract}
Any opinions expressed here are those of the author(s) and not those of IZA. Research published in this series may include views on policy, but the institute itself takes no institutional policy positions.

The Institute for the Study of Labor (IZA) in Bonn is a local and virtual international research center and a place of communication between science, politics and business. IZA is an independent nonprofit organization supported by Deutsche Post Foundation. The center is associated with the University of Bonn and offers a stimulating research environment through its international network, workshops and conferences, data service, project support, research visits and doctoral program. IZA engages in (i) original and internationally competitive research in all fields of labor economics, (ii) development of policy concepts, and (iii) dissemination of research results and concepts to the interested public.
\end{abstract}

IZA Discussion Papers often represent preliminary work and are circulated to encourage discussion. Citation of such a paper should account for its provisional character. A revised version may be available directly from the author. 
IZA Discussion Paper No. 5712

May 2011

ABSTRACT

\section{Too Far to Go? Does Distance Determine Study Choices?}

A number of studies have long shown that the probability of studying at university is influenced by the distance to the next university. This study shows for the first time that distance to university also influences the choice of subject/faculty and institution. Moreover, these findings are important because the distance effect in terms of these decisions is associated with significantly less risk of endogeneity than the effect in the analysis of the willingness and ambition to attend university. The results also show that distance does not influence study choices among students from the highest socioeconomic group, a finding that further indicates that distance to university is an expression of differences in the cost of a university education.

JEL Classification: I21, I23, R10

Keywords: distance-to-university, subject choice, university choice, Switzerland

Corresponding author:

Stefan C. Wolter

University of Bern

Centre for Research in Economics of Education

Schanzeneckstrasse 1

$\mathrm{CH}-3001$ Bern

Switzerland

E-mail: stefan.wolter@vwi.unibe.ch 


\section{Introduction ${ }^{1}$}

Efficient university education systems depend on universities competing for talented students, so that students can choose the universities and subjects that best meet their inclinations and abilities, and that potential students do not have to forego a university education because they are unable to afford it. That in many countries the majority of university students attend a nearby institution suggests that student mobility may not be sufficiently large to achieve optimum productive and allocative efficiency in the university education system. The influence of distance-to-university on the probability of opting for university education, as demonstrated in the literature, also raises the question of whether, in the presence of such unequal distribution of opportunity for university access (for more on the associated inequity, see e.g. López Turley 2009), human capital is being used to its full potential everywhere. For these and other reasons, the geographical density of available universities and the elasticity of individual demand for university education as a function of distance-to-university are important variables for education policy.

Although the correlation between distance-to-university and the probability of studying is, as just stated, well covered in the empirical literature (see Tinto 1973 for a very early example), whether the correlation is genuinely causal is still not absolutely clear. First, the place of residence might be an expression of other, non-observable factors that influence both the place of residence and the probability of studying. Educationally privileged groups tend to live nearer to a university than educationally underprivileged groups. Hence, a decision not to study at university might be due to an educationally underprivileged background, not the cost of a university education. If such a background also correlates with the distance-to-university, this distance would not be a suitable tool for estimating the impact of the distance-to-university on the probability of studying or on educational outcomes ${ }^{2}$. Second, access to university is not totally free in

\footnotetext{
${ }^{1}$ The authors wish to thank Mr. Roman Rosenfellner for his valuable help, especially with calculating the distance variables and participants of the ESPE 2010 conference in Essen and Natalie Reid for comments and helpful suggestions. Results of the present study have also been published previously in German in: Denzler, Stefan and Wolter, Stefan C. (2010): Der Einfluss des lokalen Hochschulangebotes auf die Studienwahl, Zeitschrift für Erziehungswissenschaft, 13, 683706.

${ }^{2}$ Economic literature commonly uses the significant influence of distance-to-university on study decisions as an instrumental variable for estimating education effects. If distance is a measure of cost differences in university education but distance-to-university has no influence on potential results of education, then distance is a suitable tool for unbiased estimation of the effect of a university education on salary and other educational outcomes (Card 1993 and 2001). The distance variable remains as popular an instrumental variable as ever, despite criticism of the underlying assumptions (e.g. Curie \& Moretti 2003, Dee 2004 or Long 2008).
} 
most countries but subject to entry barriers such as admission tests, tuition costs and other fees, all of which may vary significantly from university to university. Even though empirical analyses control for many of these differences taking the complex interactions between distance, selection and study fees fully into account is still difficult because selective and less selective universities do not follow a random geographical distribution pattern in a country.

This paper therefore presents an empirical re-evaluation of the effect of distance-to-university on study decisions. The analysis is free of unobservable selection decisions and the associated endogeneity problems, and is also based on data adjusted to the question at hand. Our contribution to the existing literature comprises four points that make our analyses of the distance-touniversity effects more pertinent than other analyses:

First, rather than investigating the effect of distance on the decision whether or not to study; instead, it compares study decisions in terms of the selected field of study and the preferred university among all Maturanden (Swiss school-leavers qualified to attend university by having passed the Matura exam) who have opted for university study. The advantage of this approach is that potentially endogenous factors that might be factors in deciding whether to study in the first place, such as an educationally disadvantaged background or the expectations of parents and local peers with respect to education, may play a less important role in our analysis. Analyzing choice of subject and institution rather than the inclination to study at all makes particular sense for Switzerland, a country in which only slightly more than $10 \%$ of young people qualified to study at university decide not to do so. ${ }^{3}$

Second, Switzerland is particularly suitable for investigating these questions because Maturanden qualify to study at all universities and in all subjects (the sole exception being a restriction on numbers in German-speaking Switzerland for the study of medicine). Thus both the choice of university and the choice of subject is an individual decision not subject to limitations imposed by the universities. In other words, the universities themselves cannot select the best students. In addition, all universities charge very low fees that are virtually identical across all universities and hence should have no influence on where a person chooses to study. Finally, Switzerland has no tradition of either universities themselves or private donors funding grants to support students, so that no such factor will affect the choice of university or indeed the field of study.

Third, the unique dataset used here allows for the inclusion of a large number of personal characteristics, such as motives for studying as control variables. Including these variables provides a better picture of alternative explanations to

\footnotetext{
${ }^{3}$ For completeness, we add that when we looked empirically at the decision to study, it showed as expected no distance-dependency. In a situation where practically all Maturanden go on to study, the factors behind a decision not to study tend to be attributable to highly individual preferences and motives.
} 
distance-to-university and thus reduces the probability of the decision is being attributable to those alternative factors.

Fourth, although Switzerland has a small geographical area and an extensive public transportation network, travel distances may still be substantial because of the country's topography. This paper therefore calculates actual travel distances to potential universities for all individuals in the sample, unlike the usual method in the literature of using imprecise geographical distances such 'as the crow flies'.

The paper is structured as follows: section 2 a) presents theoretical explanations of the influence of place of residence and its distance to the next university on decisions for or against studying, b) summarizes the existing empirical literature, and c) develops our working hypotheses. Section 3 describes the Swiss university system. Section 4 presents the data for empirical analysis and the operationalizations, and section 5 shows the empirical results. Section 6 concludes.

\section{Theory, empirical method and hypotheses}

\subsection{Theoretical explanations for distance effects}

Various explanations exist for the effect of geographical distance to university on study behaviour, i.e. specifically the probability of studying at all. The possible reasons can be divided into four categories:

a) Selection effects: for example educationally underprivileged sections of the community tend to be from areas located far from universities.

b) Peer effects: similar sections of the community (e.g. academics, unskilled workers, migrants) live in similar locations at similar distances from universities; they influence each other mutually in terms of their study decisions.

c) Local roots: individuals are rooted in their local environment (social networks, sports clubs, etc.) and are unwilling to leave them, i.e. they would rather not study than have to give up their social networks.

d) Cost: distance is associated with cost, i.e. both direct costs (travel costs, accommodation outside the parental home) and opportunity costs.

One can interpret hypotheses a) and b) as indicating that study decisions are influenced not by distance-to-university but by other factors pertaining to the 
choice of residence. The non-causal relationship of distance to study decisions in this case could manifest if the same people were to live far from a university, would not display any other study decisions than if they were to live near a university. However, if these reasons explained the effects of distance on study probability, the distance to the next university would also be useless as an instrumental variable for analysis of educational outcome.

With the latter two hypotheses c) and d), distance-to-university could have a causal effect on study decisions, either for monetary or non-monetary reasons.

Whether or not distance-to-university has a causal effect on study behaviour, one might attempt to exclude selection effects via control variables to create a ceteris paribus situation (which is unlikely to succeed in a convincing manner), or to select a research question that would not be affected by the individual's choice of residential location. In that case, selection effects should no longer be of any relevance.

\subsection{Empirical literature}

Classical distance-to-university literature investigates the effect of geographical distance to the next university on the probability of embarking on university education. Most empirical studies confirm a statistically negative effect of distance on probability of studying (see Frenette 2006 for Canada or Alm and Winters 2009 for a single US state). The argumentation that distance-touniversity has a causal effect on study probability is backed up by among other things, the observation that academic abilities were distributed in a nongeographically dependent manner. In other words potential students' aptitude for study does not correlate with place of residence. Furthermore the observation that potential students from higher socioeconomic groups were not subject to distance effects, suggests that the distance effect is a causal cost effect, not a selection effect (see e.g. Spiess \& Wrohlich 2010). However, both arguments can be rebutted because they do not rule out the influence of other, unobserved factors.

As previously mentioned, the non-causal relationship between distance and study probability would be apparent were individuals to display the same study decisions if they lived near a university. This circumstance was utilized by, for instance, Frenette (2009) and Curie and Moretti (2003) in their analyses of the effects of the establishment of new universities. If the distance effect were not causal, the availability of a new university in a region previously at a large distance from universities would not affect study probability in that region. As, however, the local availability of a new university has a positive impact on student numbers in a given region, distance logically has a causal effect.

A slightly different approach is to investigate not study probability as a dependent variable of distance but the choice of a particular university, type of university or particular subject. Denzler and Wolter (2009) observe in 
Switzerland that the probability of starting a course of studies at a university of teacher education increases the farther a person lives from an academic university. The distance effect comes into play because universities of teacher education are more densely distributed geographically than academic universities. A similar approach is adopted by Griffith and Rothstein (2009), who investigated applications to selective colleges and established that the probability of applying for a place at a selective college declines as a function of distance. The counterargument that the results are attributed erroneously to distance would apply only if the study fitness of potential students were not subject to random geographical distribution.

\subsection{Hypotheses}

This paper combines two of the analysis methods used in the cited literature. First, it investigates the effect of distance-to-university on specific choice of subject and institution. Second, it also examines this effect in the case of the establishment of a new university. The objective in either case is not to decide whether the probability of studying in the first place is affected by distance-touniversity but whether the choice of study subject or location is distance dependent.

The first case concerns the probability of studying at the Swiss Federal Institute of Technology in Zurich (ETH Zurich), which distinguishes itself from other universities in German-speaking Switzerland not only through its high international reputation but also because it has subjects (e.g. engineering and architecture) not available at the other universities. As it is reasonable to assume that an inclination for subjects offered only at ETH Zurich is equally distributed geographically, then the probability of enrolling at ETH Zurich should not depend on geographical distance if distance-to-university truly has no causal effect on study behaviour.

The second case study looks at whether proximity to the University of Lucerne, established in 2000 and offering only a very limited range of academic fields, increases the probability of studying the subjects that it offers. Assuming again that the preference for specific subjects does not fundamentally depend upon the subjects available locally, then in the absence of distance restrictions we should observe an approximately equal distribution of choice of study subjects in all regions. However, if students were subject to distance restrictions, then the probability of studying the subjects available at a local university with limited specialities would increase with proximity to that university.

For further differentiation of possible reasons for distance effects, the analysis takes a variety of control variables into account. Subject profiles at upper secondary schools enable observers to control for any peer effects, as experience shows that the choice of study subject is influenced by the major subject studied at upper secondary school and the study choices of peers in the same school 
class. Two typical leisure time activities, sports and scouts, are used for investigating whether involvement in local social networks might be the factor determining choice of university, i.e. by negatively affecting the probability of being willing to study at a more distant university. We also analyse socioeconomic background in interaction with distance. If the monetary aspect of distance is what affects choice of university study, no such effect should be apparent for well-off students, as they would be subject to little or no monetary restrictions. If a distance effect were to be found for socioeconomically privileged students, this finding would cast doubt on the proposition that distance reflects monetary aspects determining choice of university.

\section{University landscape and access to university in Switzerland}

In Switzerland, students who have successfully completed the final exams after upper-secondary level - the Matura exam (baccalaureate or university entrance diploma) - have free access to all studies at university level (with the previously mentioned exception of studies of medicine in German speaking Switzerland) in Switzerland. Therefore, as a rule, a qualified school-leaver (Maturand) is free to choose any university and any subject anywhere in Switzerland.

The large majority (about two-thirds) of school leavers with a university entrance diploma choose to study at a cantonal university or at one of the two Swiss Federal Swiss Federal Institutes of Technology (ETHs), located in Zurich and Lausanne. A smaller number (about one-quarter) opt for a university of applied sciences or a university of teacher education. Most qualified school leavers who choose a university of applied sciences do so because these institutions have arts, health and social work departments not available at the academic universities. More than $90 \%$ of qualified school leavers go on to study at one of the three types of universities. ${ }^{4}$ This high level of transition when compared with other countries is attributable, among other factors, to the stricter selection of students at the secondary school level. School-leavers with a university entrance diploma currently make up about only $20 \%$ of a given birth cohort.

\subsection{Structure of the Swiss university landscape}

Switzerland has 10 cantonal universities, three of which (Lucerne, St. Gallen, Tessin) do not offer the full range of university faculties but instead focus on two to three areas. Switzerland also has two ETH, with a marked focus on

\footnotetext{
${ }^{4}$ The $90 \%$ applies to the whole of Switzerland. The proportion of qualified school leavers not opting for university education was $5 \%$ in our sample, which covers only German-speaking Switzerland.
} 
engineering and science faculties, and they offer some courses not available at any other Swiss university. The ETHs - one in German-speaking and one in French-speaking ${ }^{5}$ Switzerland - also have special status because of their outstanding international reputation. ${ }^{6}$ The ETH in Zurich is of special interest in this paper because the desire to study a subject available exclusively at the ETH is unlikely to depend on geographical proximity or distance to the ETH. The same holds true for the desire to study at the ETH because of that institution's reputations for research excellence.

As for the three universities in Lugano ${ }^{7}$, Lucerne and St. Gallen, the first two are new institutions, and St. Gallen ${ }^{8}$ is a university that emerged from a commercial academy (founded in the $19^{\text {th }}$ century, later achieving the status of a university specializing in business administration). For this paper, the new University of Lucerne is of importance because it dates from as recently as 2000 and has focused very strongly on a single faculty (law). The Maturanden whose study decisions this paper examines were born before this university was established. Thus, given the relatively low mobility of the Swiss population, that the parents' choice of residential location was affected by its establishment is extremely unlikely.

\subsection{Financial entry barriers}

Although practically no institutional barriers exist for qualified school leavers to access university, and while fees are not high (on average SFR 1500 per year), money may still remain a factor influencing potential student decisions. As most universities are located in expensive cities with high housing and living costs, the cost of living is the main factor likely to have a strong influence on where to study.

Swiss Federal Statistical Office (SFSO) figures indicate that students living in the parental home require a monthly average of 1300 Swiss francs (BFS 2005, 2008) to cover the cost of living (including fees). This cost of living rise to an average of 1800 Swiss francs for students not living with their parents. ${ }^{9}$ Even today,

\footnotetext{
${ }^{5}$ Not covered in our paper as our sample of students covers only German-speaking cantons.

${ }^{6}$ ETH Zurich took 23rd place in the Academic Ranking of World Universities in 2009 (SHANGHAI RANKING), giving it the fourth-best score for universities outside the U.S.

7 The University of Lugano in Italian-speaking Switzerland is of little interest to our analysis because practically no students from German-speaking Switzerland attend it.

${ }^{8}$ The research question as to whether the universities located in the region influence study decisions could of course also be investigated on the basis of the older university of St. Gallen. Such investigation reveals a higher incidence of business studies as the subject of choice for qualified school leavers whose nearest university is St. Gallen (19\% compared with an average of $14 \%$ for all qualified school leavers). However, this difference is not statistically significant, perhaps also due to the smaller number of observations for this particular case.

${ }^{9}$ To earn the full amount through paid work, a student would have to invest about $20 \%$ of his or her time in long-term paid work. Using so much time for paid work has become difficult in some subjects because of the rigid curricula that followed the Bologna reform process.
} 
students pay for approximately $40 \%$ of their living expenses by engaging in paid work alongside their studies (BFS 2005). Self-financing opportunities, however, are limited by two factors: first, work opportunities for students heavily depend upon the economic situation (Messer and Wolter, 2010) and second, ever more heavily structured study plans are creating time-management restrictions that make it harder for students to work while studying. Third-party funding opportunities are also relatively limited in Switzerland, because grants and bursaries are given only to students whose parents have very low incomes and practically no assets, and because very few loan opportunities from either private or public sources exist. As a result, only $15 \%$ of today's students are recipients of a grant/bursary or loan (BFS 2005, 25) ${ }^{10}$.

That relatively high financial contributions from parents are necessary for studying in Switzerland, that the cost of living virtually doubles for students unable to stay in the parental home, and that opportunities for obtaining grants or loans are relatively limited suggest that the choice of actual study location depends on geographical proximity to a university.

\section{Data and methods}

\subsection{Sample}

The empirical analyses are based on a representative sample of 1400 qualified school-leavers in nine German-speaking Swiss cantons. Secondary school students were asked shortly before their final exam (Matura) about their university and job aspirations. As many students had to enrol for their first semester at university around the time of the interview, the survey took place when soon-to-be school leavers had to decide what training or educational course to follow. Thus the statements generated relate not to a study decision already implemented but a specific decision to be made in the very immediate future.

A multistage cluster sample was designed for the survey, and the sampling involved systematic selection at the cantonal level - or, for small cantons, a full survey of all upper secondary schools. At the second stage, within this selection of schools, individual senior classes were selected on a random basis.

The following investigations of distance effects on choice of subject or choice of institution (university or ETH) are limited to qualified school-leavers who aspire to a university education after school, i.e. who wish to study at one of the 10 cantonal universities or at one of the two ETHs. A genuine comparison of the decisions that students make in selecting a field of study is possible only in this particular population. Those students opting, for example, to study art, music or

${ }^{10}$ The proportion of grantees fluctuates significantly amongst cantons, ranging from less than $10 \%$ in Zurich and Bern to $30 \%$ and more in Wallis, Graubünden and Jura (BFS 2008). 
teaching automatically choose a different type of university that is not easily comparable with an academic university and therefore merits separate analysis (Denzler \& Wolter 2009).

Hence the dataset for our analyses covers only those aspiring to an academic university education. This group corresponds to approximately two-thirds of all qualified school leavers ( $\mathrm{N}=933)$. Of the remaining qualified school leavers, approximately $80 \%$ said they intended to study at a university of applied sciences or teacher training university. The remainder were unwilling or still unable to decide on a course of studies.

\subsection{Data collection}

Data acquisition took place in March 2006 by means of questionnaires distributed to entire final-year classes. The written survey took place according to standardized criteria during regular school hours under the supervision of the class teachers. This method was intended to achieve maximum data quality and relatively homogeneous class samples with a low non-response rate ${ }^{11}$. The adjusted total sample comprises 1402 observations.

\subsection{Operationalizations}

Students were asked about both professional and their training or education aspirations. The surveys also elicited personal data (gender, age, family setting, and leisure time activities), socioeconomic group (parents' education, job status and type of housing) and current schooling situation. The final-year students' major subjects were profiled and summarized as follows: languages, mathematics/science, business/law and music/fine arts. We used the most recent grades in the major subjects to rate academic attainment and standardized individual grades using the average grades for the classes. Among the grades elicited, mathematics grades were found to be the most reliable predictors of choice of subject and university; therefore, the effects of the other grades are not presented separately in the empirical analysis. Motives and preferences in terms of study choice were elicited on the basis of multiple-choice items, and scales were formed through factor analyses. We use items such as 'scientific orientation' and 'career orientation', as empirical analysis shows that these two motive groups are useful in explaining differences in subject choices.

\footnotetext{
${ }^{11}$ Response rate: 0.88 . Most of the non-responses resulted from to the absence of individual students from the classroom when the surveys were carried out (alternative classes, illness, etc.), not because students declined to participate. Therefore, classical non-response analysis was not done. In addition, classes with a response rate below 0.66 and those likely to result in biased participation owing to systematic absences were excluded from the sample.
} 


\subsection{Distance dummies}

To investigate the influence of geographical proximity of universities on study decisions, we calculated the distance to the nearest university for each student by determining the time taken for the shortest public transport route from the place of residence to the station at the university location ${ }^{12}$. This method ensures that remote areas with poor public transport access are properly taken into account, as would not be the case for a linear measurement of distance. Travel distances with other methods of transport (e.g. car) were not calculated because the use of private transport among students in Switzerland is rare.

On the basis of individual distance mass (travel time), we set up an additional dummy variable for the catchment area of the University of Lucerne. The value of the dummy variable is 1 if the travel distance to that university is the shortest, and 0 where another university is accessible within a shorter time. To test the robustness of this variable, we set up another two dummy variables as an alternative. These represent both larger and smaller catchment areas. The first variable (LU-small) takes on a value of 1 if the University of Lucerne is at least 10 minutes (one way) quicker to reach than any other university. The second variable (LU-large) still assumes a value of 1 if an alternative university is no more than 10 minutes quicker to reach, i.e. attending the University of Lucerne would involve more time spent in travelling.

\subsection{Models}

The empirical analyses are based on the following probit model, in which the study choice y (whether a specific subject or a specific university) is set in relation to a specific catchment area (Lucerne) or local university (ETH), while controlling for a number of other influencing factors.

$$
y_{i}=\beta_{0}+\beta_{1} X_{i}+\beta_{2} P_{i}+\beta_{3} S_{i}+\beta_{3} M_{i}+\beta_{4} H_{i}+\varepsilon_{i}
$$

In this equation, $X$ is a vector taking distance-to-university into account (dummy variable for a specific university or catchment area), $P$ is a vector comprising personal characteristics and socioeconomic background, $S$ comprises variables relating to schooling situation (school profile control, intended to cover peer effects and others), $M$ comprises individual motives and preferences, and vector $H$ comprises leisure time activities (sports and scouts) that might affect the choice of subject and the choice of university location. ${ }^{13}$

\footnotetext{
${ }^{12}$ Calculations based on the electronic travel time calculation of the Swiss Federal Rail System (Schweizerische Bundesbahnen, SBB).

${ }^{13}$ All regression models were estimated with the survey command (including weighting factors for sample probability), as it involves a cluster sample. These adjustment methods examine the
} 
Two different regression models (probit models) are estimated. Model 1 estimates the probability of wanting to study at the ETH; this model investigates the effect of distance (measured in travel time) to the ETH on study decisionmaking. Model 2 estimates the probability of choosing to study law. The variable of interest here is the one indicating whether the University of Lucerne (which specializes in law) is the nearest university.

\section{Results}

\subsection{Descriptive results}

Of the total of 933 qualified school leavers who opt for university study, an average of $13 \%$ choose to pursue a degree in law. Even from a purely descriptive point of view, the Lucerne catchment area has a significantly higher proportion of school leavers choosing to study law. Eighteen percent of qualified school leavers in the catchment area of the University of Lucerne choose law, as compared with only $12 \%$ outside Lucerne (see also table 1 in the appendix).

ETH Zurich, offering degrees in specific degrees like engineering and architecture is the institution of choice for roughly one-quarter of Swiss-German school leavers who opt for university. The average travelling distance to the nearest university for the whole sample is approximately half an hour; the average distance for an average potential student to the ETH is about 50 minutes. In other words, the vast majority of potential students could study at a university that is quicker to reach than the ETH.

\subsection{Results of probit regression}

\subsubsection{Studying at ETH}

Table 2 shows that the distance effect has a negative effect on choosing to study at the ETH. The effect is significant if the full model with all control variables is estimated and an indication of non-linearity exists in terms of the distance effect (not presented here) at the $10 \%$ level of significance. While the socioeconomic status (SES) has no fundamental impact on opting to study at the ETH, the interaction of distance variables with socioeconomic status shows that only school leavers from low and intermediate socioeconomic groups (SES 1 and SES 2 ) display a significant distance effect (model 5). The combined effect of distance and SES 3 is not significantly different from 0, i.e. no significant distance barriers are detected for school leavers from the highest socioeconomic group. Classification by socioeconomic background, therefore, shows that primarily middle class adolescents choose not to study at ETH because of distance from that university. That students from the lowest socioeconomic group are not

variance of an estimator in a complex sample in relation to the variance of an estimator in a simple random sample. 
more subject to the distance effect than middle class students can be attributable to their access to grants and bursaries not generally available to middle class students.

Not surprisingly, the ETH is the institution of choice particularly for school leavers with secondary school mathematics grades in the highest quartile. If investigation of distance effect is limited to school leavers with the best mathematics grades (model 3 in table 4), the distance effect is no longer significantly different from 0 , i.e., distance does not stop top-ranking school leavers from studying at the ETH. ${ }^{14}$ This inelasticity in respect to distance for individuals with high educational attainment probably occurs because the expected returns (and indeed the probability of successfully completing a course of studies at ETH) are likely to correlate positively with high ability. Therefore, choosing the ETH is worthwhile for high-ability students despite the higher costs involved in studying there. Adding socioeconomic background to the mix of factors shows that the inelasticity in terms of distance through good mathematics grades comes into play particularly for students from socioeconomically privileged backgrounds, whereas it applies to only a limited extent to students from the bottom two socioeconomic groups.

\subsubsection{Choice of faculty at a local specialist university (law at the University of Lucerne)}

The data for the Lucerne catchment area (see table 3) confirm the hypothesis stated at the outset: all the specifications (see robustness checks with various catchment area definitions, models 5 and 6) make clear that geographical proximity to the University of Lucerne significantly increases the probability of choosing to study law. Broken down by socioeconomic status (SES), qualified school leavers from the highest socioeconomic status (SES 3) are generally more likely to be interested in studying law than those from the middle and lower socioeconomic groups. By contrast, interaction with the distance variable (see table 5, model 1) shows that - exactly as seen for ETH study probability - the top socioeconomic group is not subject to a significant distance effect. In other words, qualified school leavers from the top socioeconomic group near the University of Lucerne are not more likely to opt to study law. Again, individuals from the middle and low socioeconomic groups are these whose choices are significantly influenced by distance.

\footnotetext{
${ }^{14}$ That university institutions with a very good research reputation tend to be protected against negative distance effects can also be seen in Alm and Winters (2009), who show that the institutions with the greatest distance elasticity with respect to student demand are the two-year colleges, while the demand for study places is virtually non-distant-dependent for the researchbased universities.
} 
The correlation between academic attainment and choice of faculty is negative with respect to good mathematics grades and the probability of studying law. ${ }^{15}$ Interacting mathematics grades with the distance variable does not reveal a significant distance effect for students with good mathematics grades. This finding shows that proximity to a particular university does not limit the study decisions of school leavers with very good grades. The implication for local universities is that they must recruit their students mainly from the less socioeconomically privileged and less academically able school leavers, who are on average subject to heavier distance restrictions.

\section{Conclusions}

This paper investigates the effect of proximity to a university both on choice of university and on choice of a particular subject. The Swiss educational system is ideal for empirical investigation of these questions because students in Switzerland are basically free to choose any university and subject, and because fees for studying at Swiss universities are uniformly low. In other words, assuming that the study decisions of students in Switzerland are not heavily influenced by the decisions of the universities themselves is reasonable.

The empirical results show that the distance to the nearest university significantly influences both decisions for two reasons. First, the probability of studying a subject available at only one university decreases as a function of distance to that university. Second, and conversely, the probability of studying a very specific subject increases with proximity to a university offering only a limited range of subjects.

Breakdown of potential students by socioeconomic group further shows that students from socioeconomically privileged homes are not subject to distance restrictions with respect to their study decisions. One interpretation is that the reason for any observed significant influence of distance effects on study decision is that increasing distance to a university indeed increases the cost of studying. Further breakdown by educational attainment of potential students shows that, for the top school leavers, distance to a particular university does not affect their study decisions.

Three conclusions for policy makers can be drawn from the empirical data:

First, a relatively large proportion of potential students are subject to significant distance restrictions in their choice of university and subject. These restrictions can limit both the allocative and the productive efficiency of the university system. Allocative efficiency is impaired because not all students are free to

\footnotetext{
${ }^{15}$ Analysis of the correlation between school grades in the mother tongue (German) and the probability of studying law reveals a positive effect: in relation to the subject of German, the better students choose to study law.
} 
make the study decisions of their first choice. Specialist universities show evidence of a certain degree of supply-induced demand in terms of the subjects available. Productive efficiency is impaired because distance restrictions for students reduce competition amongst universities. The greater the distance restrictions facing the students, the higher the likelihood of local monopolies for suppliers.

Second, distance restriction reveals an equity problem in that only those students from less socioeconomically privileged backgrounds are restricted in their decisions. The equity problem would be negligible only if the universities available were qualitatively and quantitatively identical throughout the country an unrealistic assumption at best.

Third, the distance restrictions differ in their implications for the different types of university. Our results show that prestigious universities (similar to selective colleges in the U.S.; see Hoxby 2009) are in a position to maintain demand even among potentially distance-restricted students, in the category of top achievers. This finding also means, however, that the average university is even more likely to be restricted to recruiting only from amongst the less mobile students and thus has to be commensurately less selective. 


\section{References}

Alm, J. \& J.V. Winters (2009). Distance and intrastate college student migration, Economics of Education Review, Vol. 28(6), 728-738.

BFS (2005). Soziale Lage der Studierenden in der Schweiz 2005. Neuenburg: Bundesamt für Statistik.

BFS (2008). Die soziale Dimension an den Hochschulen. Die Schweiz im europäischen Vergleich. Neuenburg: Bundesamt für Statistik.

Card, D. (1993). Using geographic variation in college proximity to estimate the return to schooling, NBER Working Paper, No. 4483.

Card, D. (2001). Estimating the return to schooling: progress on some persistent econometric problems, Econometrica, Vo. 69 (5), 1127-1160.

Curie, J. \& E. Moretti (2003). Mother's education and the intergenerational transmission of human capital: Evidence from college openings, Quarterly Journal of Economics, Vol. 118 (4), 1495-1532.

Dee, T. (2004). Are there civic returns to education? Journal of Public Economics, Volume $88(9-10), 1697-1720$

Denzler, S. \& S.C. Wolter (2009). Sorting into teacher education: How the institutional setting matters, Cambridge Journal of Education, Vol. 39 (4), 423-441.

Frenette, M. (2006). Too far to go on? Distance to school and university participation, Education Economics, Vol. 14 (1), 31-58.

Frenette, M. (2009). Do universities benefit local youth? Evidence from the creation of new universities, Economics of Education Review, Vol. 28, 318-328.

Griffith, A.L. \& D. S. Rothstein (2009). Can't get there from here. The decision to apply to a selective college, Economics of Education Review, Vol. 28, 620-628.

Hoxby, C. (2009). The changing selectivity of American colleges, NBER Working Paper No. 15446.

Long, M.C. (2008). College quality and early adult outcomes, Economics of Education Review, Vol. 27 (5), 588-602.

López Turley, R.N. (2009). College proximity: mapping access to opportunity, Sociology of Education, Vol. 82 (2), 126-146.

Messer, D. \& S.C. Wolter (2010). Time-to-degree and the business cycle, Education Economics, 18(1), 111-123.

Spiess, K.C. \& K. Wrohlich (2010). Does distance determine who attends a university in Germany?, Economics of Education Review, 29, 470-479.

Tinto, V. (1973). College proximity and rates of college attendance, American Educational Research Journal, Vol. 10 (4), 277-293. 


\section{Appendices}

Table 1: $\quad$ Descriptive statistics

Dependent variables

\begin{tabular}{lccrrr} 
variable & Obs. & Mean & Std. Dev. & Min & Max \\
\hline LU-dummy & 933 & 0.191 & 0.393 & 0 & 1 \\
LU-large & 933 & 0.213 & 0.410 & 0 & 1 \\
LU-small & 933 & 0.147 & 0.354 & 0 & 1 \\
ETH-dummy & 933 & 0.245 & 0.431 & 0 & 1
\end{tabular}

Indpendent variables

\begin{tabular}{lrrrrr} 
variable & Obs. & Mean & Std. Dev. & Min & Max \\
\hline dist_U & 933 & 0.677 & 0.759 & 0 & 5.233 \\
Woman & 933 & 0.501 & 0.500 & 0 & 1 \\
Age (centred) & 933 & -0.056 & 0.756 & -2.249 & 1.751 \\
ses1 & 933 & 0.342 & 0.475 & 0 & 1 \\
ses2 & 933 & 0.480 & 0.500 & 0 & 1 \\
ses3 & 933 & 0.178 & 0.383 & 0 & 1 \\
p_1 & 933 & 0.293 & 0.455 & 0 & 1 \\
p_2 & 933 & 0.304 & 0.460 & 0 & 1 \\
p_3 & 933 & 0.229 & 0.421 & 0 & 1 \\
p_4 & 933 & 0.174 & 0.379 & 0 & 1 \\
mquart_4 & 933 & 0.274 & 0.446 & 0 & 1 \\
science & 933 & 0.248 & 0.973 & -2.635 & 2.243 \\
career & 933 & 0.132 & 0.994 & -2.828 & 1.897 \\
sports & 933 & 3.545 & 3.764 & 0 & 20 \\
scouts & 933 & 0.507 & 1.649 & 0 & 17
\end{tabular}

Explanations:

LU-dummy Variable is equal to 1 , if travelling time to the University of Lucerne is the quickest

LU-small Variable is equal to 1 , if travelling time to the University of Lucerne is at least 10 minutes quicker than to any other university

LU-large Variable is equal to 1 , if travelling time to the University of Lucerne is no more than 10 minutes longer than to any other university

ETH-dummy Variable is equal to 1 if ETH is the preferred institution for studying

dist_U

Distance to ETH

SES 1

SES 2

SES 3

P_1

P_2

P_3

P_4

mquart_4

Science

Distance to the next university (measured in travelling time with public transport)

Distance to ETH Zurich (measured in travelling time with public transport, in hours)

Lower middle class

Middle class

Higher middle class and upper class

Major at upper secondary school (Gymnasium): Languages

Major at upper secondary school (Gymnasium): Mathematics and Natural sciences

Major at upper secondary school (Gymnasium): Economics and Law

Major at upper secondary school (Gymnasium): Music/Arts or Pedagogy/Psychology

Dummy highest quartile of grades in mathematics

Career

Study motives: Interest in science and research

Study motives: professional career

Sports Leisure activity: sports (in numbers of hours per week)

Scouts Leisure activity: scouts (in numbers of hours per week) 
Table 2: Probability of studying at the ETH, controlling for distance to the ETH (Probit-Regression)

\begin{tabular}{|c|c|c|c|c|}
\hline & $(1)$ & $(2)$ & (3) & Marginal effects (3) \\
\hline Distance to ETH & $\begin{array}{l}-0.17 \\
(0.17)\end{array}$ & $\begin{array}{l}-0.14 \\
(0.14)\end{array}$ & $\begin{array}{l}-0.25 \\
(0.10)^{*}\end{array}$ & $\begin{array}{l}-0.07 \\
(0.03)^{*}\end{array}$ \\
\hline SES 1 & & $\begin{array}{c}0.11 \\
(0.18)\end{array}$ & $\begin{array}{c}0.11 \\
(0.16)\end{array}$ & $\begin{array}{c}0.03 \\
(0.04)\end{array}$ \\
\hline SES 2 & & \multicolumn{3}{|c|}{ reference category } \\
\hline SES 3 & & $\begin{array}{l}-0.28 \\
(0.17)\end{array}$ & $\begin{array}{l}-0.01 \\
(0.15)\end{array}$ & $\begin{array}{l}-0.00 \\
(0.04)\end{array}$ \\
\hline Age & & $\begin{array}{l}-0.15 \\
(0.08)+\end{array}$ & $\begin{array}{l}-0.12 \\
(0.10)\end{array}$ & $\begin{array}{l}-0.03 \\
(0.02)\end{array}$ \\
\hline Woman & & $\begin{array}{l}-0.91 \\
(0.17)^{* *}\end{array}$ & $\begin{array}{l}-0.60 \\
(0.13)^{* *}\end{array}$ & $\begin{array}{l}-0.16 \\
(0.04)^{* *}\end{array}$ \\
\hline P_1 & & & $\begin{array}{c}0.27 \\
(0.21)\end{array}$ & $\begin{array}{c}0.07 \\
(0.06)\end{array}$ \\
\hline P_2 & & & $\begin{array}{l}1.48 \\
(0.23)^{* *}\end{array}$ & $\begin{array}{c}0.48 \\
(0.08)^{* *}\end{array}$ \\
\hline P_3 & & & \multicolumn{2}{|c|}{ reference category } \\
\hline$P_{-} 4$ & & & $\begin{array}{c}0.59 \\
(0.25)^{*}\end{array}$ & $\begin{array}{c}0.18 \\
(0.08)^{*}\end{array}$ \\
\hline mquart_4 & & & $\begin{array}{l}0.59 \\
(0.10)^{* *}\end{array}$ & $\begin{array}{l}0.18 \\
(0.04)^{* *}\end{array}$ \\
\hline Science & & & $\begin{array}{c}0.21 \\
(0.06)^{* *}\end{array}$ & $\begin{array}{l}0.06 \\
(0.02)^{* *}\end{array}$ \\
\hline Career & & & $\begin{array}{c}0.00 \\
(0.06)\end{array}$ & $\begin{array}{c}0.00 \\
(0.02)\end{array}$ \\
\hline Sports & & & $\begin{array}{c}0.03 \\
(0.01)^{*}\end{array}$ & $\begin{array}{c}0.01 \\
(0.00)^{*}\end{array}$ \\
\hline Scouts & & & $\begin{array}{l}-0.03 \\
(0.06)\end{array}$ & $\begin{array}{l}-0.01 \\
(0.02)\end{array}$ \\
\hline Constant & $\begin{array}{l}-0.74 \\
(0.11)^{* *}\end{array}$ & $\begin{array}{l}-0.36 \\
(0.18)^{*}\end{array}$ & $\begin{array}{l}-1.62 \\
(0.25)^{* *}\end{array}$ & \\
\hline$F$ & 0.90 & 8.99 & 15.70 & \\
\hline $\mathrm{N}$ & 933 & 933 & 933 & \\
\hline
\end{tabular}

Survey Probit Regression (standard errors are corrected for cluster sampling; weights for sampling probability) level of significance: $+p<.10,{ }^{*} p<0.05, * * p 0.01$ 
Table 3: Probability to study law controlling for the catchment area of the University of Lucerne (Probit-Regression)

\begin{tabular}{|c|c|c|c|c|c|c|c|}
\hline & (1) & $(2)$ & (3) & (4) & (5) & (6) & Marginal effects (4) \\
\hline LU-dummy & $\begin{array}{c}0.26 \\
(0.15)+\end{array}$ & $\begin{array}{c}0.27 \\
(0.12)^{*}\end{array}$ & $\begin{array}{c}0.39 \\
(0.18)^{*}\end{array}$ & $\begin{array}{l}0.55 \\
(0.17)^{* *}\end{array}$ & & & $\begin{array}{c}0.10 \\
(0.04)^{*}\end{array}$ \\
\hline LU-large & & & & & $\begin{array}{c}0.54 \\
(0.17)^{* *}\end{array}$ & & \\
\hline LU-small & & & & & & $\begin{array}{l}0.55 \\
(0.19)^{* *}\end{array}$ & \\
\hline SES 1 & & $\begin{array}{c}0.11 \\
(0.14)\end{array}$ & $\begin{array}{c}0.13 \\
(0.14)\end{array}$ & $\begin{array}{c}0.16 \\
(0.15)\end{array}$ & $\begin{array}{c}0.16 \\
(0.15)\end{array}$ & $\begin{array}{c}0.16 \\
(0.14)\end{array}$ & $\begin{array}{c}0.03 \\
(0.02)\end{array}$ \\
\hline SES 2 & & reference & category & & & & \\
\hline SES 3 & & $\begin{array}{c}0.46 \\
(0.22)^{*}\end{array}$ & $\begin{array}{c}0.35 \\
(0.18)+\end{array}$ & $\begin{array}{c}0.39 \\
(0.19)^{*}\end{array}$ & $\begin{array}{c}0.39 \\
(0.19)^{*}\end{array}$ & $\begin{array}{c}0.39 \\
(0.19)^{*}\end{array}$ & $\begin{array}{c}0.07 \\
(0.04)\end{array}$ \\
\hline Age & & $\begin{array}{l}-0.05 \\
(0.10)\end{array}$ & $\begin{array}{l}-0.08 \\
(0.09)\end{array}$ & $\begin{array}{l}-0.10 \\
(0.10)\end{array}$ & $\begin{array}{l}-0.10 \\
(0.10)\end{array}$ & $\begin{array}{l}-0.10 \\
(0.10)\end{array}$ & $\begin{array}{l}-0.01 \\
(0.02)\end{array}$ \\
\hline Woman & & $\begin{array}{c}0.30 \\
(0.12)^{*}\end{array}$ & $\begin{array}{c}0.17 \\
(0.13)\end{array}$ & $\begin{array}{c}0.21 \\
(0.14)\end{array}$ & $\begin{array}{c}0.21 \\
(0.14)\end{array}$ & $\begin{array}{c}0.22 \\
(0.14)\end{array}$ & $\begin{array}{c}0.03 \\
(0.02)\end{array}$ \\
\hline P_1 & & & $\begin{array}{l}-0.02 \\
(0.22)\end{array}$ & $\begin{array}{c}0.06 \\
(0.23)\end{array}$ & $\begin{array}{c}0.06 \\
(0.23)\end{array}$ & $\begin{array}{c}0.06 \\
(0.23)\end{array}$ & $\begin{array}{c}0.01 \\
(0.03)\end{array}$ \\
\hline P_2 & & & $\begin{array}{l}-0.95 \\
(0.29) * *\end{array}$ & $\begin{array}{l}-0.60 \\
(0.34)+\end{array}$ & $\begin{array}{l}-0.60 \\
(0.34)+\end{array}$ & $\begin{array}{l}-0.60 \\
(0.34)+\end{array}$ & $\begin{array}{l}-0.07 \\
(0.03)^{*}\end{array}$ \\
\hline P_3 & & & \multicolumn{2}{|c|}{ reference category } & & & \\
\hline P_4 & & & $\begin{array}{l}-0.51 \\
(0.24)^{*}\end{array}$ & $\begin{array}{l}-0.36 \\
(0.27)\end{array}$ & $\begin{array}{l}-0.35 \\
(0.27)\end{array}$ & $\begin{array}{l}-0.35 \\
(0.27)\end{array}$ & $\begin{array}{l}-0.04 \\
(0.03)\end{array}$ \\
\hline mquart_4 & & & $\begin{array}{l}-0.55 \\
(0.18)^{* *}\end{array}$ & $\begin{array}{l}-0.42 \\
(0.19)^{*}\end{array}$ & $\begin{array}{l}-0.42 \\
(0.19)^{*}\end{array}$ & $\begin{array}{l}-0.42 \\
(0.19)^{*}\end{array}$ & $\begin{array}{l}-0.05 \\
(0.02)^{*}\end{array}$ \\
\hline Science & & & & $\begin{array}{l}-0.26 \\
(0.09) * *\end{array}$ & $\begin{array}{l}-0.25 \\
(0.09)^{* *}\end{array}$ & $\begin{array}{l}-0.26 \\
(0.09)^{* *}\end{array}$ & $\begin{array}{l}-0.04 \\
(0.02)^{*}\end{array}$ \\
\hline Career & & & & $\begin{array}{l}0.41 \\
(0.08)^{* *}\end{array}$ & $\begin{array}{l}0.41 \\
(0.08)^{* *}\end{array}$ & $\begin{array}{c}0.42 \\
(0.08)^{* *}\end{array}$ & $\begin{array}{l}0.06 \\
(0.01)^{* *}\end{array}$ \\
\hline Sports & & & & $\begin{array}{l}-0.03 \\
(0.02)\end{array}$ & $\begin{array}{l}-0.03 \\
(0.02)\end{array}$ & $\begin{array}{l}-0.03 \\
(0.02)\end{array}$ & $\begin{array}{l}-0.00 \\
(0.00)\end{array}$ \\
\hline Scouts & & & & $\begin{array}{l}-0.05 \\
(0.04)\end{array}$ & $\begin{array}{l}-0.05 \\
(0.04)\end{array}$ & $\begin{array}{l}-0.05 \\
(0.04)\end{array}$ & $\begin{array}{l}-0.01 \\
(0.01)\end{array}$ \\
\hline Constant & $\begin{array}{l}-1.18 \\
(0.13)^{* *}\end{array}$ & $\begin{array}{l}-1.49 \\
(0.15)^{* *}\end{array}$ & $\begin{array}{l}-1.08 \\
(0.21)^{* *}\end{array}$ & $\begin{array}{l}-1.27 \\
(0.24)^{* *}\end{array}$ & $\begin{array}{l}-1.26 \\
(0.24)^{* *}\end{array}$ & $\begin{array}{l}-1.26 \\
(0.24)^{* *}\end{array}$ & \\
\hline $\mathrm{F}$ & 3.04 & 3.63 & 4.93 & 10.39 & 10.40 & 9.52 & \\
\hline $\mathrm{N}$ & 933 & 933 & 933 & 933 & 933 & 933 & \\
\hline
\end{tabular}

Survey Probit Regression (standard errors are corrected for cluster sampling; weights for sampling probability) level of significance: $+p<.10,{ }^{*} p<0.05,{ }^{* *} p<0.01$ 
Table 4: $\quad$ Probability of studying at the ETH controlling for distance to the ETH (Probit-regression) - with interaction variables

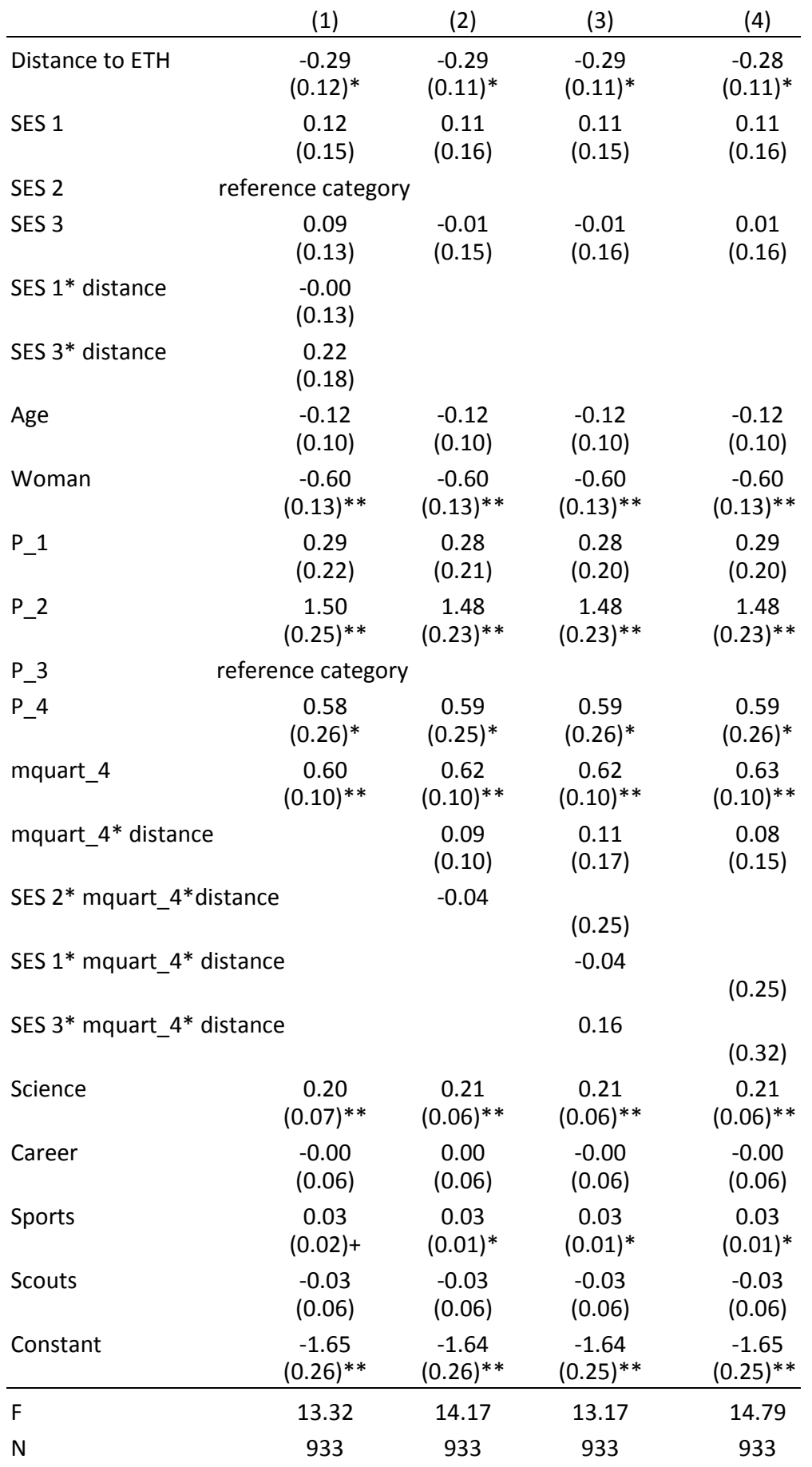

Survey Probit Regression (standard errors are corrected for cluster sampling; weights for sampling probability) level of significance: $+p<.10,{ }^{*} p<0.05,{ }^{*} p<0.01$ 
Table 5: Probability to study law controlling for the catchment area of the University of Lucerne (Probit-regression) - regression with interaction variables

\begin{tabular}{|c|c|c|}
\hline & (1) & $(2)$ \\
\hline LU_dummy & $\begin{array}{c}0.30 \\
(0.11)^{*}\end{array}$ & $\begin{array}{c}0.70 \\
(0.19)^{* *}\end{array}$ \\
\hline SES 1 & $\begin{array}{l}-0.03 \\
(0.16)\end{array}$ & $\begin{array}{c}0.17 \\
(0.14)\end{array}$ \\
\hline SES 2 & reference category & \\
\hline SES 3 & $\begin{array}{c}0.42 \\
(0.21)+\end{array}$ & $\begin{array}{c}0.42 \\
(0.19)^{*}\end{array}$ \\
\hline SES 1*LU_dummy & $\begin{array}{c}0.76 \\
(0.37)^{*}\end{array}$ & \\
\hline SES 3*LU_dummy & $\begin{array}{l}-0.40 \\
(0.35)\end{array}$ & \\
\hline Age & $\begin{array}{l}-0.09 \\
(0.10)\end{array}$ & $\begin{array}{l}-0.09 \\
(0.10)\end{array}$ \\
\hline Woman & $\begin{array}{c}0.24 \\
(0.15)\end{array}$ & $\begin{array}{c}0.20 \\
(0.14)\end{array}$ \\
\hline P_1 & $\begin{array}{c}0.05 \\
(0.22)\end{array}$ & $\begin{array}{c}0.05 \\
(0.23)\end{array}$ \\
\hline P_2 & $\begin{array}{c}-0.70 \\
(0.31)^{*}\end{array}$ & $\begin{array}{c}-0.60 \\
(0.34)+\end{array}$ \\
\hline P_3 & reference category & \\
\hline P_4 & $\begin{array}{l}-0.32 \\
(0.25)\end{array}$ & $\begin{array}{l}-0.38 \\
(0.27)\end{array}$ \\
\hline mquart_4 & $\begin{array}{c}-0.40 \\
(0.19)^{*}\end{array}$ & $\begin{array}{l}-0.24 \\
(0.19)\end{array}$ \\
\hline mquart_4*LU_dummy & & $\begin{array}{c}-1.06 \\
(0.52)^{*}\end{array}$ \\
\hline Science & $\begin{array}{c}-0.27 \\
(0.10)^{* *}\end{array}$ & $\begin{array}{c}-0.27 \\
(0.09)^{* *}\end{array}$ \\
\hline Career & $\begin{array}{c}0.44 \\
(0.07)^{* *}\end{array}$ & $\begin{array}{c}0.42 \\
(0.08)^{* *}\end{array}$ \\
\hline Sports & $\begin{array}{l}-0.03 \\
(0.02)\end{array}$ & $\begin{array}{l}-0.03 \\
(0.02)\end{array}$ \\
\hline Scouts & $\begin{array}{l}-0.05 \\
(0.04)\end{array}$ & $\begin{array}{l}-0.05 \\
(0.04)\end{array}$ \\
\hline Constant & $\begin{array}{c}-1.24 \\
(0.23)^{* *}\end{array}$ & $\begin{array}{c}-1.30 \\
(0.24)^{* *}\end{array}$ \\
\hline $\mathrm{F}$ & 9.56 & 10.49 \\
\hline $\mathrm{N}$ & 933 & 933 \\
\hline
\end{tabular}

Survey Probit Regression (standard errors are corrected for cluster sampling; weights for sampling probability) level of significance: $+p<.10, * p<0.05, * * p<0.01$ 